\title{
Financial Distress Dengan Model Altman Dan Springate
}

\author{
Firda Nosita $^{1)^{*}}$, Jumriaty Jusman ${ }^{1)}$ \\ Sekolah Tinggi Ilmu Ekonomi Pancasetia \\ Jl. A. Yani KM. 5,5 Banjarmasin 706, Indonesia \\ *Email: firda.nosita@gmail.com
}

\begin{tabular}{|c|c|}
\hline Artikel Info & ABSTRAK \\
\hline $\begin{array}{c}\text { Dikirim: } \\
27 \text { Mei 2019 } \\
\text { Revisi: } \\
10 \text { Agustus } 2019 \\
\text { Diterima: } \\
27 \text { Agustus } 2019\end{array}$ & $\begin{array}{l}\text { Perbankan syariah di Indonesia dihadapkan persaingan yang semakin ketat dengan perbankan } \\
\text { konvensional. Pangsa pasar perbankan syariah yang masih kecil, rendahnya literasi perbankan syariah di } \\
\text { masyarakat serta keterbatasan aset ataupun sumber daya manusia menjadi masalah bagi perbankan } \\
\text { syariah di Indonesia. Perbankan syariah perlu menilai kesehatan bisnisnya guna mengukur seberapa kuat } \\
\text { mereka dapat bertahan ditengah era e-business dan fintech saat ini. Penelitian ini mengukur kesehatan } \\
\text { keuangan bank umum syariah nasional devisa yang terdiri dari empat bank dengan menggunakan model } \\
\text { Altman Z-Score dan Springate S-Score. Data diperoleh dari laporan keuangan dan menggunakan rasio } \\
\text { untuk menghitung nilai skor. Dari hasil perhitungan menggunakan model Altman Z-Score, Bank BNI } \\
\text { Syariah, Bank Mega Syariah, Bank Muamalat dan Bank Syariah Mandiri berada pada zona aman, atau } \\
\text { tidak terindikasi mengalami kesulitan keuangan. Sedangkan dengan menggunakan model Springate S- } \\
\text { Score, Bank Muamalat menunjukkan kondisi kesulitan keuangan dengan nilai S-Score dibawah 0,862. } \\
\text { Kondisi kesulitan keuangan sangat dipengaruhi oleh besarnya penjualan, laba, manajemen aset dan } \\
\text { tingkat Non Performing Financing. Perlu adanya inovasi produk dan layanan serta pembenahan dalam hal } \\
\text { manajemen pembiayaan. Disamping itu, perbankan syariah juga dituntut untuk memperluas pangsa } \\
\text { pasarnya dengan memanfaatkan teknologi informasi agar dapat bersaig dengan perbankan konvensional. }\end{array}$ \\
\hline
\end{tabular}

Kata Kunci : Kesulitan Keuangan, Perbankan Syariah, Indonesia, Altman Z-Score, Springate S-Score

\section{Financial Distress with the Altman and Springate Models}

\section{ABSTRACT}

Islamic Banking in Indonesia is faced with increasingly fierce competition with conventional banking. The low market share, the low literacy and the limited asset or human resources are the problems of islamic banking in Indonesia. Islamic Banking needs to asses the health of its business in order to measure how strong they can survive amid the e-business and fintech era nowadays. The study measure the financial health of the national foreign exchange Islamic banks consisting of four banks using the Altman Z-Score and Springate S-Score methods. The data obtained from financial report and use the ratios to calculate the score. By using Altman Z-Score, four of bank namely BNI Syariah, Bank Mega Syariah, Bank Muamalat and Bank Syariah Mandiri are in the "safe" zone. While, by using Springate SScore, Bank Muamalat tend to be has financial distress with an S-Score value below of 0,862. The financial distress is strongly influenced by the amount of sales, profits, asset management and the level of Non Performing Financing (NPF). Islamic banking need to develop the product and service innovation and also improvement in financing management. In addition, islamic banking is also required to expand its market share by utilizing information and technology to be able to compete with conventional banking.

Keyword : financial distress, Islamic Banking, Indonesia, Altman Z-Score, Springate S-Score

Cara Sitasi :

Nosita, F., \& Jusman, J. (2019). Financial Distress Dengan Model Altman Dan Springate. Jurnal Ilmiah Manajemen dan Bisnis, 20(2), 1-17. https://doi.org/10.30596/jimb.v20i2.3120. 


\section{Jurnal Ilmiah Manajemen dan Bisnis}

\section{PENDAHULUAN}

Krisis ekonomi global yang terjadi pada tahun 2008 dimulai dari kondisi ekonomi di Amerika Serikat yang dihadapkan pada krisis Subprime Mortgage. Masalah subprime mortgage ini berawal dari ekpansi besarbesaran dalam kredit perumahan oleh perbankan. Selain itu, Bank Investasi raksasa Lehman Brothers telah menjadi korban dari krisis kredit macet di Amerika Serikat. Dampak krisis ekonomi global akibat runtuhnya Lehman Brothers juga dirasakan di Indonesia yaitu terkoreksinya rupiah di tahun 2008 dan juga mengakibatkan gejolak penurunan di pasar modal Indonesia (May, 2015).

Sedangkan sebelumnya, di Indonesia juga pernah mengalami krisis moneter yang berdampak ke berbagai sektor, termasuk perbankan yang banyak menghadapi masalah kredit macet dan mengalami kesulitan keuangan (financial distress). Hal inilah yang mendorong timbulnya berbagai macam penelitian mengenai model kebangkrutan sebagai early warning system bagi para regulator, legislator pembuat kebijakan, auditor, pemilik perusahaan, pemegang obligasi atau investasi dan bahkan masyarakat umum.

Krisis perbankan sangat berdampak bagi kesehatan di sektor keuangan. Kondisi ini tentu akan membuat kekhawatiran bagi pelaku ekonomi yang sangat bergantung pada perbankan.Bank-bank yang mengalami kesulitan keuangan (financial distress) akan lebih tertekan jika sudah mengarah pada kebangkrutan karena adanya biaya-biaya tambahan. Dalam upaya menekan biaya yang berkaitan dengan kebangkrutan, para regulator dan para manajer perusahaan berupaya bertindak cepat mencegah kebangkrutan atau menurunkan biaya kegagalan tersebut yaitu dengan mengembangkan metode Early Warning System (EWS) untuk memprediksi permasalahan potensial yang terjadi pada perusahaan. Namun, teknik statistik yang paling sering digunakan untuk menganalis kebangkrutan adalah analisis parametik yaitu model logit MDA (multivariate discriminant analysis), sedangkan model non parametik baru sering digunakan di akhir- akhir ini seperti trait recognition dan artficial neural network atau ANN.

Perusahaan membuat laporan keuangan dalam rangka memberikan gambaran mengenai kinerja keuangannya. Semua pihak dapat menilai kinerja manajemen perusahaan dengan melihat kinerja keuangannya. Selain itu, bagi manajemen, laporan keuangan adalah tolak ukur keberhasilan kebijakankebijakan keuangan yang diambil oleh manajemen perusahaan selama satu periode. Kebijakan keuangan seperti kebijakan investasi, kebijakan pendanaan dan kebijakan distribusi pendapatan akan terukur dengan melihat angka-angka pada laporan keuangan. Disamping itu, laporan keuangan memberikan berbagai informasi-informasi penting mengenai apa yang telah dilakukan oleh manajemen dalam rangka penciptaan nilai dan memaksimalkan kesejahteraan pemilik perusahaan.

Bagi pemilik perusahaan, laporan keuangan menggambarkan kondisi dan posisi perusahaan saat ini dan dapat dibandingkan dengan periode-periode sebelumnya. Perusahaan dianggap memberikan nilai bagi pemilik jika pemilik dapat menikmati kemajuan perusahaan dengan berbagai indikator, salah satunya adalah perolehan laba. Selain pemilik, ada berbagai pihak lain yang turut membuthkan laporan keuangan perusahaan seperti manajemen, kreditur, investor, pemerintah bahkan pelanggan atau konsumen perusahaan.

Penting bagi perusahaan untuk menilai "kesehatan" perusahaannya dalam rangka mengambil kebijakan-kebijakan keuangan yang akan berdampak pada pencapaian tujuan. Jika perusahaan menghadapi kesulitan keuangan (financial distress), maka akan 
mendorong pada kondisi default dan pada akhirnya bermuara pada kebangkrutan yangberbiaya tinggi. Untuk itu, penting bagi perusahaan untuk mengukur kemampuan mereka dalam berbagai aspek, seperti kemampuan memenuhi kewajiban, kemampuan melakukan penjualan, kemampuan menciptakan laba, kemampuan mengelola aset dan lainnya.

Penyebab kesulitan keuangan dan krisis perbankan dapat dilihat dari faktor makro, yaitu kebijakan dan kontrol dari pemerintah atau perencana serta faktor mikro, yaitu kontrol perbankan seperti strategi, penilaian kredit yang buruk serta kegagalan operasional lainnya (Ali, 2006). Pengawasan yang lemah menjadi salah satu sumber kegagalan, namun regulasi yang berlebihan, pengawasan yang terlalu ketat dan peraturan yang sangat membatasi juga dapat menyebabkan kegagalan perbankan. Kelemahan dalam metode akuntansi serta prosedur audit pada perbankan syariah dapat menutupi dan menunda realisasi masalah illikuiditas dan insolvensi oleh pengawas dan deposan. Selain itu, moral hazard memainkan peran penting dalam perbankan syariah yang dikenal dengan sistem profit-loss sharing dan berbagai faktor lainnya yang dapat menjadi penyebab kegagalan perbankan syariah (Ali, 2006).

Disektor keuangan, perbankan Islam telah lama berperan dalam menggerakkan perekonomian, baik secara global maupun bagi perekonomian Indonesia. Perbankan Syariah di Indonesia baru mulai beroperasi sejak dikeluarkannya Undang-undang No.7 Tahun 1992 tentang perbankan. Dalam undang-undang tersebut salah satu pasalnya memungkinkan untuk memberi peluang untuk bank menyalurkan kreditnya berdasarkan bagi hasil. Sejak awal Bank Indonesia sebagai otoritas yang berkewajiban mengembangkan dan mengatur industri perbankan Syariah, mengambil inisiatif aktif untuk ikut mengembangkan industri ini. Bank Indonesia melihat industri ini memiliki potensi yang besar untuk berkontribusi dalam menciptakan sistem keuangan nasional yang stabil dan kemudian dapat memberikan manfaat bagi perekonomian Indonesia.

Sebagai negara dengan jumlah penduduk muslim terbesar di dunia, Indonesia menjadi pasar yang memiliki prospek besar di masa mendatang bagi pertumbuhan pembiayaan syariah. Pada tahun 2017, Indonesia menduduki peringkat ketujuh Islamic Finance Country Index (IFCI) setelah sebelumnya sempat berada di posisi keenam di tahun 2016. Peringkat satu IFCI diduduki oleh negara Malaysia berturut-turut di tahun 2016 dan 2017. IFCI bergantung pada beberapa faktor seperti jumlah perbankan syariah, ketersediaan badan atau lembaga yang mengawasi aktivitas lembaga keuangan syariah, jumlah populasi muslim dan beberapa faktor lainnya.

Garbois et al (2012) menyebutkan bahwa terjadi penurunan pertumbuhan dan profitabilitas pada perbankan syariah yang mengharuskan mereka mengubah strateginya. Di negara-negara seperti Kerajaan Arab Saudi, Uni Emirat Arab, Kuwait dan Bahrain, pertumbuhan aset perbankan syariah mengalami penurunan di tahun 2009 dan 2010. Selama bertahun-tahun mengalami pertumbuhan yang signifikan melebihi perbankan konvensional di banyak negara, namun pertumbuhannya semakin melambat. Disamping itu, meskipun perbankan syariah secara umum mencetak pertumbuhan yang lebih baik dibandingkan perbankan konvensional, namun perbankan syariah tidak secara konsisten mendapatkan profitabilitas yang lebih baik dibandingkan perbankan konvesnional. Beberapa perbankan syariah kecil berjuang bertahun-tahun untuk mendapatkan laba, sedangkan beberapa lainnya terkena dampak buruk dari krisis ekonomi (Garbois et al., 2012)

Beberapa tantangan perbankan syariah menurut Garbois, et al (2012) adalah size, 
persaingan, standarisasi dan regulasi dan struktur biaya. Perbankan syariah lebih kecil dibandingkan perbankan konvensional pesaingnya di pasar domestik. Jumlah perbankan dan jasa keuangan syariah terus bertambah disaat pertumbuhan pasar sedang turun. Selain itu, tidak adanya standarisasi dan regulasi pada instrumen keuangan syariah menjadi tantangan bagi perbankan syariah. Meskipun mengalami pertumbuhan yang tinggi, namun perbankan syariah tidak secara konsisten meraih laba, terutama pada saat krisis keuangan global. Hal ini disebabkan oleh manajemen risiko dan efektivitas operasional yang masih lemah.

$$
\text { Zulaikah dan Laila }
$$
membandingkan kondisi financial distress bank Syariah di Indonesia dengan Bank Islam di Malaysia sebelum dan sesudah krisis global tahun 2008 dengan menggunakan model Altman Z-Score. Bank Muamalat Indonesia, Bank Syariah Mandiri dan Bank Mega Syariah menjadi sampel bank Syariah di Indonesia, sedangkan Affin Islamic Bank Berhad, Bank Muamalat Malaysia Berhad, CIMB Islamic Bank Berhad dan RHB Islamic Bank Berhad sebagai sampel bank Islam dari Malaysia. Mereka menemukan bahwa sebelum krisis global tahun 2008, nilai Altman Z-Score bank-bank Syariah di Indonesia termasuk kategori safe, sedangkan bank-bank Islam di Malaysia masuk kategori grey area. Namun setelah krisis global, Bank Islam di Malaysia menunjukkan performa yang lebih unggul dalam hal rasio laba ditahan terhadap total aset (Retained Earning to Total Asset Ratio). Namun rata-rata rasio nilai buku ekuitas terhadap total liabilitas (Book Value of Equiy to Total Liability Ratio) bank Syariah di Indonesia lebih besar dibandingkan bank Islam di Malaysia. Hal ini menunjukkan bahwa bank Islam di Malaysia cenderung lebih rentan terhadap kondisi financial distress.

Ratna dan Marwati (2018) menganalisis faktor-faktor yang dapat digunakan untuk memprediksi kondisi financial distress pada perusahaan yang delisting dari Jakarta Islamic Index periode tahun 2012 sampai 2016. Mereka menemukan bahwa variabel operating capacity yang diproksikan dengan perputaran total aset menjadi salah satu alasan mengapa perusahaan berpotensi mengalami kesulitan keuangan. Sedangkan tingkat leverage dan profit margin belum mampu menjadi predictor kesulitan keuangan. Dari data yang didapatkan, perusahaan yang mengalami kesulitan keuangan sebagian besar masih memiliki total aset yang tinggi, yang dapat mengindikasikan bahwa mereka masih mampu membayar kewajibannya.

Kurniawati \& Kholis(2004) membandingkan prediksi kesulitan keuangan dengan menggunakan metode Altman, Grover dan Springate. Dengan menggunakan sampel perusahaan perbankan syariah di Indonesia yang delisting antara periode 2010 sampai tahun 2014 yaitu sebanyak 55 perusahaan. Dengan akurasi tertinggi, metode Grover GScore memprediksi sebanyak 2 perusahaan bangkrut, sedangkan dengan metode Springate S-Score, terdapat 13 perusahaan diprediksi bangkrut dan dengan metode Altman Z-Score, sebanyak 15 perusahaan diprediksi bangkrut (Kurniawati dan Kholis, 2014).

Husein dan Pambekti (2014) menggunakan 132 perusahaan yang terdaftar pada Daftar Efek Syariah (DES) di tahun 2009 sampai 2012 sebagai sampel. Mereka menyimpulkan bahwa model Altman, Zmijewski, Springate dan Grover dapat digunakan untuk memprediksi kesulitan keuangan. namun model Zmijewski merupakan model yang paling tepat digunakan untuk memprediksi kesulitan keuangan karena memiliki tingkat signifikansi tertinggi.

Junaidi (2016) melakukan prediksi tingkat kesehatan dan kebangkrutan bank Syariah di Indonesia. Ia menyimpulkan bahwa model Grover, Altman dan Springate 


\section{Jurnal Ilmiah Manajemen dan Bisnis}

dapat digunakan untuk memprediksi kebangkrutan bank Syariah di Indonesia. Sedangkan model Zmijewski tidak dapat digunakan untuk memprediksi kebangkrutan. Africa(2016) menemukan bahwa rasio pinjaman terhadap simpanan atau LDR (Loan to Deposit Ratio) merupakan rasio yang paling tepat digunakan untuk menentukan kesulitan keuangan sebagai deteksi dini kebangkrutan pada Bank Umum Go Public di Indonesia.

Dari total aset, Bank Mandiri Syariah dan Bank Muamalat menduduki peringkat kesatu dan kedua bank Syariah terbesar di Indonesia, namun total aset ini masih jauh kecil dibandingkan dengan perbankan Syariah di Malaysia. Malaysia adalah negara yang memiliki tingkat pengetahuan dan kesadaran keuangan Syariah tertingggi bahkan dibandingkan dengan Indonesia yang memiliki populasi muslim terbesar di dunia (Hendarsyah, 2018)

Dengan menggunakan sampel perbankan Islam dan konvensional di Mesir, Fayed (2013) menemukan bahwa perbankan konvensional memiliki kinerja yang superior dibandingkan perbankan Islam dalam hal profitabilitas, likuiditas, manajemen risiko kredit dan solvensi. Profitabilitas yang diukur dari ROA dan ROE perbankan Islam lebih kecil dibandingkan dengan perbankan konvensional, yang berarti bahwa perbankan konvensional lebih mampu dalam menghasilkan return dibandingkan perbankan Islam. Namun erbankan Islam lebih unggul dalam manajemen solvensi.

Iqbal et al (2018) mengukur potensi kesulitan keuangan pada bank-bank syariah di Indonesia periode 2016 sampai 2016. Dengan menggunakan S-score, ditemukan bahwa hampir seluruh sampel sebanyak 11 bank berada pada zona grey area. Salah satu penyebabnya adalah modal kerja yang dimiliki sektor perbankan cenderung lebih kecil daripada sektor manufaktur atau perusahaan lainnya. Mereka juga menemukan bahwa bank syariah yang baru beroperasi pada awal tahun 2010 seperti Bank BNI Syariah, Bank Panin Syariah, BCA Syariah, Maybank Syariah dan Bank Victoria Syariah memiliki Z-score yang lebih tinggi, yang berarti berada pada zona safe.

Ali (2007) menyajikan fakta mengenai bangkrutnya Ihlas Finans di Turkey dan menyimpulkan bahwa pelajaran yang bisa diambil dari bangkrutnya Ihlas Finans adalah: ketika size industri keuangan Islam tumbuh, maka eksposur terhadap guncangan makro ekonomi juga meningkat. Perbankan Islam harus memonitor perkembangan ini dan siaga dalam menghadapi perkembangan dan masalah. Jika tabungan dari perbankan Islam tidak dilindungi oleh jaminan Bank Sentral, maka mereka harus berhati-hari dalam mencari pendanaan dan juga menginvestasikannya. Perbankan Islam juga harus berhati-hati dalam investasi aset yang berbunga serta menjaga porsi aset dalam bentuk likuid agar mampu memenuhi likuiditas dari nasabah. Beberapa perbankan Islam berukuran kecil dan mereka harus saling mendukung satu sama lain dibandingkan berkompetisi.

Hanif et al (2012) membandingkan perbankan konvensional dan perbankan Islam untuk membandingkan kinerjanya. Profitabilitas dan manajemen likuiditas dari perbankan konvensional lebih baik dibandingkan perbankan Islam. Namun dalam manajemen risiko kredit dan manajemen solvensi dari perbankan Islam lebih baik dibandingkan perbankan konvensional.

Plat dan Plat (2002)mendefinisikan financial distress sebagai tahap penurunan kondisi keuangan yang terjadi sebelum terjadinya kebangkrutan ataupun likuidasi. Financial distress dimulai dengan ketidakmampuan memenuhi kewajibankewajibannya, terutama kewajiban yang bersifat jangka pendek, kewajiban likuiditas, dan kewajiban dalam kategori solvabilitas. Sedangkan Hanafi (2007) menyatakan bahwa 
financial distress dapat digambarkan dari dua titik ekstrem yaitu kesulitan likuiditas jangka pendek sampai insolvable, biasanya bersifat jangka pendek, tetapi bisa berkembang menjadi parah. Indikator kesulitan keuangan dapat dilihat dari analisis aliran kas, analisis strategi perusahaan, dan laporan keuangan perusahaan.

Menurut Kordestani et al(2011) tahapan dari kebangkrutan adalah adanya latency, yaitu kondisi dimana Return on Assets (ROA) mengalami penurunan. Setelah itu, perusahan mungkin akan menghadapi tahap Shortage of Cash, yaitu tahap dimana perusahaan mengalami kekurangan kas, tidak memiliki cukup sumber dana kas untuk memenuhi kewajiban saat ini, meskipun masih mungkin memiliki tingkat profitabilitas yang kuat. Jika tahap ini tidak dapat dikendalikan oleh perusahaan dengan membuat keputusankeputusan yang tepat, maka kemungkinan besar perusahaan akan menuju ke tahap Financial distress atau kesulitan keuangan. Kondisi dimana perusahaan kesulitan dalam memenuhi kewajiban-kewajibannya. Jika kondisi kesulitan keuangan ini dibiarkan berlarut-larut tanpa pengambilan keputusan yang cepat dan tepat, maka perusahaan berpotensi menuju Bankruptcy atau kebangkrutan yang berbiaya mahal dan seringkali dihindari oleh perusahaan.

Prediksi kondisi financial distress suatu perusahaan menjadi perhatian banyak pihak. Pihak-pihak yang menggunakan model tersebut meliputi pemberi pinjaman atau kreditur, investor, pembuat peraturan (regulator) dan pemerintah. Potensi kesulitan keuangan atau kebangkrutan bermanfaat bagi pihak kreditur yang akan atau sedang mempertimbangkan untuk memberikan pinjaman kepada perusahan. Jika perusahaan yang akan diberikan pinjaman dana sedang berada pada posisi financial distress, maka kreditur akan berpotensi kehilangan atau penundaan pembayaran dana yang telah dipinjam oleh perusahaan.
Investor berkepentingan dalam menilai kesehatan suatu perusahaan. Dana yang telah ditanamkan pada suatu perusahaan diharapkan dapat bertumbuh dan menciptakan nilai serta menambah kemakmuran bagi investor atau pemegang saham. Namun jika perusahaan dimana dana ditempatkan tidak dikelola dengan baik serta tidak dapat menciptakan nilai, maka investor akan berpotensi kehilangan dananya. Sehingga penting untuk mendeteksi secara dini posisi keuangan perusahaan dalam rangka menghindari kondisi financial distress.Lembaga regulator mempunyai tanggung jawab mengawasi kesanggupan membayar hutang dan menstabilkan perusahaan individu. Hal ini menyebabkan perlunya suatu model yang aplikatif untuk mengetahui kesanggupan perusahaan membayar hutang dan menilai stabilitas perusahaan.Prediksi financial distress juga penting bagi pemerintah dan antitrust regulation.

Financial distress dapat disebabkan oleh berbagai faktor. Lizal (dalam Rahma, 2018) mengelompokkan penyebab-penyebab kesulitan keuangan dan dikenal dengan model dasar kebangkrutan atau trinitas penyebab kesulitan keuangan. Ada tiga alasan yang menyebabkan perusahaan menjadi bangkrut, . yaitu: a) Neoclassical Model, Financial distress terjadi ketika alokasi sumber daya tidak tepat mengestimasi kesulitan dilakukan dengan data neraca dan laporan laba rugi, b) Financial model. Financial distress ditandai dengan adanya struktur keuangan yang salah dan menyebabkan batasan likuiditas (liquidity constrains). Hal ini berarti bahwa walaupun perusahaan dapat bertahan hidup dalam jangka panjang, namun demikian perusahaan tersebut harus bangkrut juga dalam jangka pendek, c) Corporate Governance Model, inancial distress menurut corporate governance model adalah ketika perusahaan memiliki susunan aset yang tepat dan struktur 


\section{Jurnal Ilmiah Manajemen dan Bisnis}

keuangan yang baik namun dikelola dengan buruk.

Munculnya berbagai model prediksi kebangkrutan merupakan antisipasi dan sistem peringatan dini terhadap financial distress karena model tersebut dapat digunakan sebagai sarana untuk mengidentifikasi bahkan memperbaiki kondisi sebelum sampai pada kondisi krisis atau kebangkrutan. Hal lain yang mendorong perlunya peringatan dini adalah munculnya problematika keuangan yang mengancam operasional perusahaan. Dengan terdeteksinya lebih awal kondisi perusahaan, sangat memungkinkan bagi perusahaan, investor dan para kreditor serta pemerintah melakukan langkah-langkah antisipasi untuk mencegah agar krisis keuangan segera tertangani (Endri,2009).Ada beberapa model untuk mengukur potensi kebangkrutan perusahaan, seperti Altman Z-Score, Springate S-Score, Zmijewski, model Grover, model Fulmer dan model lainnya yang menggunakan variabel independen berbeda.

Di Malaysia, perbankan syariah didominasi oleh Maybank Islamic dan CIMB Islamic dengan total aset mencapai USD 181 Milyar. Sedangkan di Indonesia, perbankan syariah didominasi oleh Bank Syariah Mandiri dan Bank Muamalat Indonesia yang total aset nya sebesar USD 29,94 Milyar. Dengan jumlah penduduk sekitar 237 juta jiwa, dibandingkan dengan populasi Malaysia yang hanya 31,7 juta jiwa, Indonesia memiliki 13 perbankan syariah, 21 islamic windows dan 167 Bank Perkreditan Rakyat Syariah sedangkan Malaysia memiliki 16 perbankan syariah. Dari segi pangsa pasar (market share), perbankan syariah di Indonesia hanya mampu berada di angka $5,55 \%$, sedangkan di Malaysia, pangsa perbankan syariah mampu mencapai $24,82 \%$ pada tahun 2017. Berbeda dengan Indonesia, Malaysia menggunakan Top Down Approach dalam mengembangkan industri perbankan syariah nya. Sementara Indonesia menggunakan buttom up approach yang kebanyakan berasal dari dana masyarakat dan dana pemerintah yang terbatas (Fitriasari, 2012).

Tantangan yang dihadapi oleh pembiayaan syariah di Indonesia meliputi masih rendahnya literasi keuangan syariah, masih kurang beragamnya produk dan layanan yang belum memenuhi harapan masyarakat, persepsi yang kurang menyenangkan pada perbankan syariah dan tidak memadainya modal dan skala industri kecil (Hendarsyah, 2017). Tantangan lain seperti size perbankan syariah yang masih dianggap lebih kecil dari pesaing konvensional, persaingan yang semakin ketat, baik dari perbankan konvesional maupun perbankan syariah dari dalam dan luar negeri. Masalah lain seperti struktur biaya yang mempengaruhi efisiensi dan biaya operasional turut memperngaruhi pertumbuhan perbankan syariah di Indonesia.

Dalam konteks perbankan syariah, kegagalan atau kebangkrutan perbankan syariah, akan berdampak pada reputasi dari industri yang baru saja mengalami perkembangan ini, perlambatan pertumbuhan yang pada akhirnya kehilangan nasabah potensial dari sistem keuangan islam. Berbagai penelitian menguraikan penyebab kesulitan keuangan dan krisis perbankan.

Oktarina (2017) melakukan prediksi kebangkrutan dengan model Altman Z-Score pada PT.BRI Syariah. Berdasarkan hasil analisis disimpulkan bahwa kondisi keuangan PT. bank BRI Syariah menunjukkan hasil yang stabil dan sehat karena nilai z-score nya dari tahun 2011-2015 di atas 2,6. Sedangkan Hasanah (2010) memberikan bukti empiris tentang faktor-faktor yang mempengaruhi kondisi kesulitan bank, dimana faktor- faktor yang di uji dalam penentuan kondisi keuangan bank adalah rasio keuangan model Altman dan model springate dengan sampel 5 bank sehat dan 2 bank yang mengalami kondisi kesulitan keuangan. Hasil penelitian 
menunjukkan bahwa rasio keuangan model altman dan model springate memiliki daya klasifikasi atau daya prediksi untuk kondisi bank yang mengalami kesulitan keuangan.

Rahmah (2018) menggunakan Model Zmijewski, Springate, Altman Z-Score dan Grover untuk mengukur Financial distress Bank Umum Syariah Di Indonesia Periode 2012-2016. Dengan menggunakan sampel sebanyak 10 bank syariah di Indonesia, ia menunjukan bahwa dengan Model Zmijewski terdapat satu bank syariah yang berpotensi bankrut dengan tingkat akurasi 98\%, sedangkan dengan model Springate memprediksi lima belas bank syariah berpotensi bankrut dengan akurasi 70\%, Model Altman Z-Score memprediksi satu perusahaan bank syariah mengalami kebankrutan dengan akurasi 98\% dan model Grover memprediksi dua perusahaan pbank syariah mengalami kebankrutan dengan tingkat akurasi 96\%. Hasil uji KruskallWallis menunjukan terdapat perbedaan signifikan diantara keempat model prediksi kebangkrutan.

Abrori(2015)membandingkan seberapa besar potensi kebangkrutan bank syariah devisa dan non devisa dengan menggunakan metode Altman Z-Score. Dengan menggunakan sampel sebanyak 4 bank syariah devisa dan 6 bank syariah non devisa ia menunjukkan bahwa bahwa bank syariah devisa memiliki risiko kebangkrutan lebih besar daripada bank syariah non devisa. Ratarata Z-score bank Syariah devisa dalam 3 tahun rentang penelitian selalu lebih kecil daripada rata-rata Z-score pada bank Syariah non devisa.

Kamal (2012) melakukan prediksi kebangkrutan pada perusahaan perbankan yang terdaftar di Bursa Efek Indonesia dengan menggunakan metode Altman Z-score dengan sampel 20 bank. Hasil penelitian ini menunjukkan bahwa pada tahun 2008, sebanyak 95\% bank diprediksi bernilai di bawah 1,88 dan $5 \%$ berada pada grey area.
Pada tahun 2009, ada beberapa bank yang mengalami perbaikan kondisi keuangan dengan adanya $40 \%$ bank berada dalam kondisi sehat, $45 \%$ bangkrut dan $15 \%$ berada pada grey area. Sedangkan tahun 2010, mengalami peningkatan untuk kondisi sehat yaitu sebesar 55\%, 5\% grey area dan sisanya berada dalam kondisi bangkrut.

Perbankan syariah di Indonesia perlu mengukur potensi kebangkrutan usahanya ditengah semakin masifnya persaingan, terutama dengan perbankan konvesnsional serta perbankan syariah yang berasal dari luar negeri. Hal ini penting diperhatikan oleh manajemen agar dapat menjadi pertimbangan dalam segala keputusannya. Perbankan syariah yang bertumpu pada bagi hasil harus dapat menyesuaikan produk serta layanannya dengan kebutuhan keuangan masyarakat saat ini. Penelitian ini mengukur potensi kebangkrutan dengan mendeteksi financial distress menggunakan model Altman Z-Score dan model Springate pada Bank-Bank Umum Syariah yang termasuk bank devisa di Indonesia.

\section{METODE}

Sampel diambil dengan metode purposive sampling dengan kriteria: (1) Bank Umum Syariah di Indonesia yang memperoleh surat penunjukan dari Bank Indonesia untuk dapat melakukan kegiatan usaha perbankannya dalam kegiatan valuta asing; (2) Bank Umum Syariah di Indonesia yang bisa memberikan layanan yang berkaitan dengan mata uang asing misalnya transfer keluar negeri, transaksi ekspor impor, jual beli valuta asing, serta jasa-jasa valuta asing lainnya; (3) Memiliki laporan keuangan yang lengkap periode 2015-2017. Dengan kriteria tersebut, maka didapatkan empat bank syariah yang dapat dijadikan sampel, yaitu PT. Bank BNI Syariah, PT. Bank Mega syariah, PT. Bank Muamalat Indonesia, dan PT. Bank Syariah Mandiri. 


\section{Jurnal Ilmiah Manajemen dan Bisnis}

ISSN 1693-7619 (Print) I ISSN 2580-4170 (Online) Ihttp://jurnal.umsu.ac.id/index.php/mbisnis

Variabel yang akan diteliti adalah potensiFinancial Distress yang dihitung dengan menggunakan Model Altman Z-Score Modifikasi untuk perusahaan non manufaktur dan Model Springate S-Score. Nilai semua variabel independen diambil dari laporan keuangan masing-masing bank periode tahun 2015, 2016 dan 2017. Analisis dilakukan dengan persamaan dari masing-masing model:

Model Altman Z-Score Modifikasi Persamaan Model Altman ZScoreModifikasi: Z-Score $=6,56 \mathrm{X} 1+3,26$ $X 2+6,72 X 3+1,05 X 4$, Dimana:

$\mathrm{Z}=$ financial distress index

$\mathrm{X} 1=$ working capital/total asset

$\mathrm{X} 2=$ retained earnings / total asset

$\mathrm{X} 3=$ earning before interest and taxes/total asset

$\mathrm{X} 4=$ book value of equity/book value of total liabilities

Adapun nilai cut-off yang digunakan adalah mengacu pada tabel berikut:

Tabel 1: Nilai cut-off Altman Z-Score

\begin{tabular}{ccl}
\hline Nilai Z-Score & Kategori & \multicolumn{1}{c}{ Keterangan } \\
\hline $\mathrm{Z} \leq 1,11$ & Distress & $\begin{array}{l}\text { Bank telah mengalami } \\
\text { kesulitan keuangan }\end{array}$ \\
$1,11<\mathrm{Z} \leq 2,6$ & Grey Area & $\begin{array}{l}\text { Bank kemungkinan akan } \\
\text { mengalami kesulitan } \\
\text { keuangan }\end{array}$ \\
$\mathrm{Z}>2,6$ & Safe & $\begin{array}{l}\text { Bank aman atau tidak } \\
\text { mengalami kesulitan } \\
\text { keuangan }\end{array}$ \\
\hline
\end{tabular}

Sumber: Iqbal et al, 2018

\section{Model Springate S-Score}

Persamaan Model Springate yang digunakan adalah:

$\mathrm{S}$-Score $=1,03 \mathrm{~A}+3,07 \mathrm{~B}+0,66 \mathrm{C}+0,4 \mathrm{D}$

Dimana:

$A=$ Working capital / Total asset

$\mathrm{B}=$ Net profit before interest and taxes / Total asset

$\mathrm{C}=$ Net profit before taxes / Current liabilities $\mathrm{D}=$ Sales $/$ Total asset adalah:
Tabel 2: Nilai cut-off Springate S-Score

\begin{tabular}{ccc}
\hline Nilai S-Score & Kategori & \multicolumn{1}{c}{ Keterangan } \\
\hline $\mathrm{S}<0,862$ & Distress & $\begin{array}{l}\text { Perusahaan tidak sehat atau berpotensi } \\
\text { mengalami kesulitan keuangan }\end{array}$ \\
$\mathrm{S}>0,862$ & $\begin{array}{c}\text { Non Financial } \\
\text { distress }\end{array}$ & Termasuk dalam kategori perusahaan sehat \\
\hline
\end{tabular}

Sumber: Iqbal et al, 2018

\section{HASIL PENELITIAN}

Penelitian ini menggunakan model Altman Z-Score modifikasi untuk perusahaan non manufaktur. Dengan menggunakan rasio WC/TO, RE/TA, EBIT/TA dan BVE/BVTL, berikut merupakan hasil prediksi financial distress pada Bank Umum Syariah Nasional (BUSN) Devisa yang terdaftar di Bank Indonesia yaitu PT. Bank BNI Syariah, PT. Bank Mega syariah, PT. Bank Muamalat Indonesia, dan PT. Bank Syariah Mandiri.

Tabel 3. Hasil Analisis Financial Distress dengan Model Altman Z-score

\begin{tabular}{|c|c|c|c|c|c|c|}
\hline $\begin{array}{c}\text { Nama } \\
\text { Perusahaan }\end{array}$ & $X_{1}$ & $\mathrm{X} 2$ & $\mathbf{X}_{3}$ & $X_{4}$ & $\mathrm{Z}$ & Keterangan \\
\hline \multicolumn{7}{|c|}{ Tahun 2015} \\
\hline $\begin{array}{l}\text { PT. Bank BNI } \\
\text { Syariah }\end{array}$ & 0.848 & 0.026 & 0.013 & 0.669 & 6,437 & Safe \\
\hline $\begin{array}{l}\text { PT. Bank Mega } \\
\text { Syariah }\end{array}$ & 0.763 & 0.004 & 0.003 & 0.936 & 6,021 & Safe \\
\hline $\begin{array}{l}\text { PT. Bank } \\
\text { Muamalat } \\
\text { Indonesia }\end{array}$ & 0.857 & 0.003 & 0.002 & 0.393 & 6,058 & Safe \\
\hline $\begin{array}{l}\text { PT. Bank Syariah } \\
\text { Mandiri }\end{array}$ & 0.841 & 0.046 & 0.005 & 0.568 & 6,297 & Safe \\
\hline \multicolumn{7}{|c|}{ Tahun 2016} \\
\hline $\begin{array}{l}\text { PT. Bank BNI } \\
\text { Syariah }\end{array}$ & 0.825 & 0.03 & 0.013 & 0.531 & 6.155 & Safe \\
\hline $\begin{array}{l}\text { PT. Bank Mega } \\
\text { Syariah }\end{array}$ & 0.841 & 0.022 & 0.025 & 1.624 & 7.462 & Safe \\
\hline $\begin{array}{l}\text { PT. Bank } \\
\text { Muamalat } \\
\text { Indonesia }\end{array}$ & 0.781 & 0.004 & 0.002 & 0.382 & 5.551 & Safe \\
\hline $\begin{array}{l}\text { PT. Bank Syariah } \\
\text { Mandiri }\end{array}$ & 0.832 & 0.045 & 0.006 & 0.569 & 6.242 & Safe \\
\hline \multicolumn{7}{|c|}{ Tahun 2017} \\
\hline $\begin{array}{l}\text { PT. Bank BNI } \\
\text { Syariah }\end{array}$ & 0.801 & 0.032 & 0.012 & 0.576 & 6.044 & Safe \\
\hline $\begin{array}{l}\text { PT. Bank Mega } \\
\text { Syariah }\end{array}$ & 0.771 & 0.03 & 0.014 & 0.924 & 6.219 & Safe \\
\hline $\begin{array}{l}\text { PT. Bank } \\
\text { Muamalat } \\
\text { Indonesia }\end{array}$ & 0.739 & 0.005 & 0.001 & 0.555 & 5.454 & Safe \\
\hline $\begin{array}{l}\text { PT. Bank Syariah } \\
\text { Mandiri }\end{array}$ & 0.833 & 0.045 & 0.006 & 0.541 & 6.219 & Safe \\
\hline
\end{tabular}

Sumber: Diolah

Dari perhitungan tabel 3, dapat dilihat bahwa dengan menggunakan model Altman Z-Score untuk semua perusahaan sampel berada pada nilai diatas 2,6 sehingga dapat disimpulkan 


\section{Jurnal Ilmiah Manajemen dan Bisnis}

ISSN 1693-7619 (Print) I ISSN 2580-4170 (Online) Ihttp://jurnal.umsu.ac.id/index.php/mbisnis

bahwa semua perusahaan sampel berada pada zona "safe" atau dapat dikatakan tidak mengalami kesulitan keuangan. Semua bank yang menjadi sampel di tiga tahun penelitian menunjukkan bahwa tidak ada indikasi kesulitan keuangan berdasarkan variabelvariabel independen seperti rasio $\mathrm{WC} / \mathrm{TO}$, RE/TA, EBIT/TA dan BVE/BVTL yang mencerminkan kemampuan perusahaan dalam mengelola aset, efisiensi penggunaan aset, investasi yang dilakukan, profitabilitas yang diperoleh serta komposisi modal dalam neraca.

Tabel diatas menunjukkan bahwa SScore Bank Muamalat Indonesia pada tahun 2016 dan 2017 mengalami penurunan dibandingkan tahun 2015. Hal ini dapat dikaitkan dengan kinerja perusahaan yang dalam beberapa tahun tersebut mengalami perlambatan serta banyaknya masalah Non Performing Financing (NPF). Bank Muamalat berbeda dengan tiga bank lainnya, Bank BNI Syariah, Bank Mega Syariah dan Bank Syariah Mandiri yang memiliki perusahaan induk yang dapat sewaktu-waktu menyuntikkan modal bagi anak usahanya sehingga dapat menopang kinerja masingmasing.

\section{Analisis Financial Distress - Model Springate}

Dengan menggunakan variabel independen yang berbeda, berikut hasil prediksi financial distress dengan model Springate Periode 2015-2017 untuk empat bank sampel:
Tabel 4. Hasil Analisis Financial distress dengan ModelSpringate S-

\begin{tabular}{|c|c|c|c|c|c|c|}
\hline $\begin{array}{c}\text { Nama } \\
\text { Perusahaan }\end{array}$ & A & B & $\mathrm{C}$ & D & $\mathrm{S}$ & Keterangan \\
\hline \multicolumn{7}{|c|}{ Tahun 2015} \\
\hline $\begin{array}{l}\text { PT. Bank BNI } \\
\text { Syariah }\end{array}$ & 0.848 & 0.013 & 0.093 & 0.106 & 1.018 & $\begin{array}{c}\text { Non-Financial } \\
\text { distress }\end{array}$ \\
\hline $\begin{array}{l}\text { PT. Bank } \\
\text { Mega Syariah }\end{array}$ & 0.763 & 0.003 & 0.018 & 0.145 & 0.865 & $\begin{array}{l}\text { Non-Financial } \\
\text { distress }\end{array}$ \\
\hline $\begin{array}{l}\text { PT. Bank } \\
\text { Muamalat } \\
\text { Indonesia }\end{array}$ & 0.857 & 0.002 & 0.012 & 0.087 & 0.931 & $\begin{array}{l}\text { Non-Financial } \\
\text { distress }\end{array}$ \\
\hline $\begin{array}{l}\text { PT. Bank } \\
\text { Syariah } \\
\text { Mandiri }\end{array}$ & 0.841 & 0.005 & 0.038 & 0.085 & 0.94 & $\begin{array}{l}\text { Non-Financial } \\
\text { distress }\end{array}$ \\
\hline \multicolumn{7}{|c|}{ Tahun 2016} \\
\hline $\begin{array}{l}\text { PT. Bank BNI } \\
\text { Syariah }\end{array}$ & 0.825 & 0.013 & 0.08 & 0.099 & 0.983 & $\begin{array}{l}\text { Non-Financial } \\
\text { distress }\end{array}$ \\
\hline $\begin{array}{l}\text { PT. Bank } \\
\text { Mega Syariah } \\
\text { PT. Bank }\end{array}$ & 0.841 & 0.025 & 0.226 & 0.108 & 1.134 & $\begin{array}{l}\text { Non-Financial } \\
\text { distress }\end{array}$ \\
\hline $\begin{array}{l}\text { Muamalat } \\
\text { Indonesia }\end{array}$ & 0.781 & 0.002 & 0.012 & 0.068 & 0.846 & Financial distress \\
\hline $\begin{array}{l}\text { PT. Bank } \\
\text { Syariah } \\
\text { Mandiri }\end{array}$ & 0.832 & 0.006 & 0.039 & 0.082 & 0.933 & $\begin{array}{l}\text { Non-Financial } \\
\text { distress }\end{array}$ \\
\hline \multicolumn{7}{|c|}{ Tahun 2017} \\
\hline $\begin{array}{l}\text { PT. Bank BNI } \\
\text { Syariah }\end{array}$ & 0.801 & 0.012 & 0.062 & 0.092 & 0.939 & $\begin{array}{c}\text { Non-Financial } \\
\text { distress }\end{array}$ \\
\hline $\begin{array}{l}\text { PT. Bank } \\
\text { Mega Syariah } \\
\text { PT. Bank }\end{array}$ & 0.771 & 0.014 & 0.074 & 0.091 & 0.922 & $\begin{array}{l}\text { Non-Financial } \\
\text { distress }\end{array}$ \\
\hline $\begin{array}{l}\text { Muamalat } \\
\text { Indonesia }\end{array}$ & 0.739 & 0.001 & 0.006 & 0.06 & 0.792 & Financial distress \\
\hline $\begin{array}{l}\text { PT. Bank } \\
\text { Syariah } \\
\text { Mandiri }\end{array}$ & 0.833 & 0.006 & 0.036 & 0.083 & 0.933 & $\begin{array}{l}\text { Non-Financial } \\
\text { distress }\end{array}$ \\
\hline
\end{tabular}

Dengan nilai cut-off kurang dari 0.862 , maka dapat disimpulkan bahwa PT. Bank Muamalat terindikasi berpotensi mengalami financial distresspada tahun 2016 dan 2017. Sedangkan PT. Bank BNI Syariah secara berturut-turut memiliki S-Score tertinggi sejak tahun 2015 sampai tahun 2017. Hasil perhitungan dengan model Springate S-Score ini berbeda dengan hasil perhitungan dengan model Altman Z-Score sebelumnya yang menyimpulkan bahwa keempat bank yang menjadi sampel berada di zona "aman". Model springate S-Score menyimpulkan bahwa PT. Bank Muamalat mulai terindikasi berpotensi mengalami financial distress.

\section{PEMBAHASAN}

Altman Z-Score menggunakan empat rasio yang dianggap dapat menggambarkan "kesehatan" sebuah perusahaan. Rasio Working Capital to Total Asset (WC/TO) digunakan untuk mengukur likuiditas terhadap total kapitalisasinya atau untuk mengukur kemampuan perusahaan dalam memenuhi kewajiban jangka pendek. Jika perusahaan mengalami kesulitan keuangan, 
modal kerja akan turun lebih cepat daripada total aset. Jika rasio ini negatif, artinya perusahaan mengalami masalah dalam memenuhi kewajiban jangka pendeknya. Berdasarkan data tahun 2015, PT. Bank Mega Syariah memiliki rasio WC/TO (X1) sebesar 0,763 dan merupakan perusahaan dengan rasio $\mathrm{WC} / \mathrm{TO}$ terendah yang mengindikasikan bahwa tingkat likuiditasnya paling rendah diantara ketiga bank lainnya. Bank Muamalat Indonesia mendapatkan rasio (X1) tertinggi dengan nilai sebesar 0,857 , yang berarti Bank Muamalat Indonesia mampu mengelolah kecukupan modalnya dengan baik. Namun di tahun 2016 dan 2017, rasio WC/TO PT. Bank Muamalat Indonesia menjadi paling rendah diantara tiga bank lainnya. Hal ini mengindikasikan bahwa terjadi penurunan kemampuan perusahaan dalam memenuhi kewajiban jangka pendeknya.

Junaidi (2016) mengukur kesehatan bank syariah di Indonesia tahun 2010 sampai 2014 dan menyimpulkan bahwa model Altman Z-Score, Springate S-Score dan Grover dapat digunakan untuk memprediksi kebangkrutan bank syariah di Indonesia. Meskipun terkadang kesimpulan yang dihasilkan berbeda antar model dan tidak sepenuhnya tepat, namun kesimpulan ini dapat dijadikan sebagai early warning system bagi perbankan syariah dalam menilai kesehatan keuangannya.

Rasio Retained Earning to Total Asset (RE/TA) menunjukkan seberapa besar bagian laba yang "diamankan" terhadap jumlah aset yang dimiliki. Rasio ini menggambarkan besarnya laba yang diinvestasikan kembali kepada aset-aset dalam rangka keputusan investasi. Tabel 3 menunjukkan bahwa rasio laba ditahan terhadap total aset terbesar secara konsisten dimiliki oleh PT. Bank Syariah Mandiri dari tahun 2015 sampai tahun 2017, sedangkan nilai rasio RE/TA terkecil secara konsisten dimiliki oleh PT. Bank Muammalat. Rasio RE/TA PT. Bank Syariah Mandiri yang bagus ditopang oleh inovasi produk seperti pembiayaan dan refocusing ke nasabah ritel. Selain itu, di tahun 2017, perusahaan induk PT. Bank Mandiri juga turut menyuntikkan setoran modal kepada PT. Bank Syariah Mandiri yang mempengaruhi rasio kecukupan modalnya. Sedangkan kondisi PT. Bank Muamalat beberapa tahun terakhir memang mengalami penurunan laba, terutama disebabkan oleh non performing financing (NPF) yang besar, permodalan yang menyusut hingga beban operasional yang tinggi. Besarnya jelas mempengaruhi perolehan laba yang akhirnya akan berdampak pada komposisi laba yang akan ditahan dan/atau diinvestasikan kembali pada aset produktif.

Pemanfaatan teknologi informasi dalam rangka menjawab tantangan global dalam layanan keuangan menjadi sangat penting diperhatikan oleh lembaga keuangan seperti perbankan. Cashless society yang tidak dapat ditekan adalah alasan mengapa perbankan harus melakukan investasi pada teknologi informasi seperti world wide wibe (www)atau aplikasi mobile dan internet banking. Selain untuk menjawab tantangan global, inovasi ini juga turut berdampak pada efisiensi bagi perusahaan, seperti pembukaan rekening tabungan online dan pengajuan kredit online tanpa harus datang ke kantor cabang. Kegiatan seperti ini dapat memangkas waktu dan biaya meskipun biaya investasi pada fasilitas ini terkadang tidak murah.

Rasio laba sebelum bunga dan pajak terhadap total aset (Earning Before Interest and Taxes to Total Asset Ratio atau EBIT/TA) menggambarkan tingkat produktivitas perusahaan dalam menghasilkan laba. Semakin tinggi rasio ini, maka dapat dikatakan perusahaan mampu menghasilkan laba yang tinggi terhadap total aset yang digunakan atau dengan kata lain seberapa efektif perusahaan menggunakan aset nya untuk menghasilkan laba. PT. Bank BNI Syariah memiliki rasio EBIT/TA tertinggi di 
tahun 2015, sedangkan pada tahun 2016 dan 2017, PT. Bank Mega Syariah lebih baik dalam menghasilkan laba. Hal ini ditopang oleh kebijakan manajemen dalam hal seleksi nasabah. Tahap ini penting bagi bank dalam rangka menekan Non Performing Financing(NPF). Jika NPF tinggi, maka akan berdampak pada perolehan laba serta biaya yang harus ditanggung oleh bank. Selain itu, perbankan adalah lembaga intermediasi yang berfungsi dalam pengumpulan dana dan penyaluran dana. Perolehan laba sangat bergantung pada efektivitas dan efisiensi dalam kedua aspek tersebut, yaitu bagaimana perbankan mencari sumber dana paling murah dan/atau memberikan kredit pada tingkat imbal hasil yang maksimal. Perolehan sumber dana dengan biaya terendah tidak terlepas dari aspek yang mendukung nasabah atau calon nasabah memutuskan untuk menempatkan dananya pada perbankan tersebut. Keputusan penempatan dana nasabah dapat dipengaruhi oleh keragaman produk, aksesabilitas, kemudahan transaksi, ketersediaan sarana, aspek teknologi informasi serta aspek-aspek lainnya. Jika dana diperoleh dengan biaya yang rendah, maka perbankan dapat mengatur biaya kredit yang juga relatif lebih murah agar dana simpanan menjadi produktif. Dalam proses pemberian kredit, perbankan tidak hanya melakukan antisipasi di awal pengajuan kredit, namun juga melakukan monitoring terhadap kelancaran pembayaran dan tindakan jika terdapat kredit macet.

Rasio Book Value of Equity/Book Value of Total Liabilities (BVE/BVL) menggambarkan nilai buku dari ekuitas terhadap nilai buku total kewajiban. Rasio ini mengukur tingkat leverage perusahaan. Kewajiban yang tinggi menimbulkan biaya yang juga tinggi, sehingga menjadi beban bagi perusahaan. Secara konsisten rasio BVE/BVL tertinggi sejak tahun 2015 sampai tahun 2017 dimiliki oleh PT. Bank Mega Syariah. Sedangkan PT. Bank Muamalat
Indonesia secara konsisten memiliki rasio BVE/BVL terendah di tahun 2015 dan 2016. Sedangkan pada tahun 2017, rasio BVE/BVL dimiliki oleh PT. Bank Syariah Mandiri.

Model spirngate lebih menekankan pada kemampuan perusahaan menciptakan laba, yang ditangkap pada rasio yang digunakan dalam persamaannya. Kemampuan perusahaan menciptakan laba tidak terlepas dari kemampuan perusahaan memanfaatkan sumber daya yang dimiliki dengan cara paling efisien. Sumber daya yang dimiliki oleh perusahaan dapat berasal dari modal sendiri maupun dari pihak eksternal seperti hutang yang menimbulkan kewajiban dan beban. Jika perusahan tidak dapat memanfaatkan sumber daya tersebut, terutama yang berasal dari hutang, maka potensi perusahaan mengalami kesulitan keuangan semakin besar.

Springate S-Score menggunakan variabel independen yang berbeda dengan model Altman Z-Score selain rasio Modal Kerja terhadap Total Aset (atau WC/TA). Jika model Altman Z-Score menggunakan rasio laba ditahan terhadap total aset, model Springate S-Score lebih menekankan pada rasio laba sebelum bunga dan pajak terhadap total aset maupun terhadap kewajiban lancarnya. Rasio ini penting untuk mengukur efisiensi penggunaan aset oleh bank untuk menghasilkan laba. Selain itu rasio laba sebelum pajak terhadap kewajiban lancar penting untuk menilai kemampuan perusahaan untuk membayar kewajiban lancar dengan memperhatikan penciptaan labanya.

Jika dilihat dari rasio laba sebelum bunga dan pajak terhadap total aset (EBIT/TA), rasio laba sebelum pajak terhadap kewajiban lancar (EBT/CL) dan rasio penjualan terhadap total aset (Sales/TA), PT. Bank Muamalat Indonesia memiliki nilai terendah dibandingkan tiga sampel lainnya di tiga tahun berturut-turut dari tahun 2015 sampai tahun 2017. Hal ini disebabkan oleh penurunan penjualan PT. Bank Muamalat 
Indonesia di tahun 2016 dan 2017 berturutturut yang akhirnya berdampak pada perhitungan rasio. Selain itu, perolehan laba sebelum bunga dan pajak PT. Bank Muamalat Indonesia di tahun 2015 tidak meningkat signifikan dan justru turun di tahun 2017.

Pada umumnya, pertumbuhan perbankan syariah membaik di tahun 2016 jika dibandingkan dengan bank umum. Meskipun penjualan PT. Bank Mega Syariah mampu meningkatkan laba sampai dengan hampir 800 persen di tahun 2016 meskipun dari segi pangsa pasar, PT. Bank Mega Syariah belum besar. Pertumbuhan ini tidak terlepas dari perubahan model bisnis dan efisiensi yang dilakukan oleh manajemen PT. Bank Mega Syariah.

Sedangkan PT. Bank Mandiri Syariah menunjukkan peningkatan kinerja yang positif dengan peningkatan pendapatan penjualan berturut-turut sejak tahun 2015. Di tahun 2016, PT. Bank Syariah Mandiri berhasil membukukan laba yang meningkat 12,38\% dibandingkan tahun 2015. Selama tahun 2017, PT. Bank Syariah Mandiri membukukan kinerja yang baik, dilihat dari pertumbuhan aset, dana pihak ketiha (DPK) pembiayaan dan kualitas pembiayaan sehingga meningkatkan laba perusahaan (syariahmandiri.co.id, 2018). Pertumbuhan tersebut ditopang oleh berbagai faktor sepeti jumlah tabungan dan giro yang meningkat, serta tersedianya dana murah (low cost fund).

PT. Bank BNI Syariah turut mencetak kinerja yang bagus beberapa tahun terakhir. Bahkan, PT. Bank BNI Syariah menerima dua penghargaan sekaligus pada Infobank Awards 2017, yaitu sbeagai Bank Syariah predikat sangat bagus selama 5 tahun berturut-turut kategiri aset diatas 25 triliun rupiah dan kategori Bank Syariah predikat sangat bagus tahun 2016 (bnisyariah.co.id, 2017). Pertumbuhan laba PT. BNI syariah tahun 2017 juga meningkat dibandingkan tahun 2016, yang ditopang oleh pertumbuhan pada pembiayaan dan Dana Pihak Ketiga.
Sebagai bank syariah tertua di Indonesia, kinerja PT. Bank Muamalat Indonesia beberapa tahun terakhir kurang menggembirakan. Masalah Non Performing Funding (NPF) yang tinggi serta laba perusahaan yang juga turun di tahun 2017 menjadi permasalahan utama PT. Bank Muamalat Indonesia. Meskipun hasil analisis dengan model Springate, PT. Bank Muamalat Indonesia berada di area financial distress berturut-turut di tahun 2016 dan 2017, namun perseroan terus berusaha memperbaiki kinerjanya dan terbukti di tahun 2018, PT. Bank Muamalat Indonesia mampu menghasilkan laba dua kali lipat dibandingkan tahun 2017 (Khadafi, 2019).

Kurnia et al. (2017) menyebutkan bahwa risiko pembiayaan bank Syariah bisa berawal dari risiko operasionalnya, karena pada penjelasan mengenai akad-akad Syariah yang terlihat dari karakteristik dari perilaku dan kualitas akhlak pelaku akad-akad tersebut. Faktanya, dalam penerapannya, akad-akad tersebut boleh jadi telah mengalami modifikasi agar sesuai dengan lingkungan bisnis bank namun makna dan esensinya tetap mengandung adanya kepercayaan yang tinggi. Budaya pengelolaan pembiayaan yang baik tercermin dari sikap para staf yang baik, yaitu memiliki pemahaman yang jelas tentang karakter bank Syariah dan risiko pembiayaan yang dapat diterima oleh bank Syariah. Manajemen juga harus peduli terhadap perkembangan budaya pengelolaan pembiayaan serta sikap pemimpin dan dukungan dari manajemen senior.

Kurnia et al (2017) mengusulkan kerangka konspetual manajemen risiko bank Syariah dalam mengantisipasi timbulnya financial distress adalah dengan: 1) akhlakul karimah/panutan, 2) manajemen kinerja, 3) segmentasi nasabah, 4) kebijakan pembiayaan diatur dan diawasi bersama-sama oleh Dewan Komisaris, Direksi dan Dewan Pengawas Syariah. Sedangkan alat mitigasi risiko 
Syariah adalah dengan mengutamakan akad Mudharabah dan Musyarakah dibandingkan akad lainnya.

Ismal (2010) menegaskan bahwa motivasi utama deposan dalam membuka akun syariah adalah (1) tujuan religius, mendukung proyek-proyek islam/syariah, (2) orientasi laba dan (3) motivasi transaksi. Dengan alasan-alasan tersebut, maka perbankan syariah dapat membuat produk atau layanan yang dapat memenuhi kebutuhan-kebutuhan religius serta proyekproyek yang mendukung syariah Islam.

Risiko pembiayaan bank syariah bisa berawal dari risiko operasionalnya, yaitu risiko yang berasal dari kualitas sumber daya manusia (Kurnia et al, 2017). Pada dasarnya, perbankan syariah berlandaskan akad-akad syariah seperti karakteristik dari perilaku dan kualitas akhlak pelaku akad-akad tersebut terutama pada akad Mudharabah dan Musyarakah. Mungkin saja dalam prakteknya, akad-akad tersebut mengalami modifikasi agar sesuai dengan lingkungan bisnis bank, namun makna dan esensi dari akad-akad syariah tetap mengandung adanya trust yang tinggi.

Aspek lain yang perlu diperhatikan adalah kesiapan dan kesigapan dari pihak Manajemen. Manajemen dituntut untuk mempersiapkan diri dalam setiap kondisi perubahan seperti perubahan hukum, peraturan, kebutuhan nasabah serta persaingan. Salah satu kegagalan manajemen adalah mempekerjakan senoir executive dari bank yang gagal. Meskipun dengan banyak pengalaman, seseorang yang pernah gagal menyelamatkan organisasi sebelumnya mungkin akan sulit untuk dipercaya dapat membawa organisasi ke dalam kondisi lebih baik, apalagi jika organisasi tersebut sedang mengalami kesulitan. Manajemen terkadang tidak menyadari pentingnya perencanaan manajemen krisis (Crisis Management Plan) yang sangat penting didunia yang penuh dengan risiko. Likuditas adalah faktor yang sangat penting diperhatikan bagi perbankan, tidak terkecuali bagi perbankan syariah. Kondisi yang tidak pasti seperti gejolak global, politik, perang dagang dan faktor lain dapat mempengaruhi kepercayaan nasabah. Hal ini harus dikelola oleh manajemen agar tidak mengalami shockketika terjadi krisis. Kegagalan Ihlas Finans di Turki adalah contoh dari kegagalan manajemen dalam menghadapi perubahan lingkungan seperti ini (Ali, 2007), dimana tidak ada perencanaan krisis, mempekerjakan senior executive yang pernah gagal dan tidak dapat melakukan adjustment dengan perubahan lingkungan.

\section{SIMPULAN}

Berdasarkan hasil prediksi financial distress dengan model Altman Z-Score, keempat bank yang dimasukkan ke dalam sampel, yaitu PT.Bank BNI Syariah, PT. Bank Mega Syariah, PT. Bank Muamalat Indonesia dan PT. Bank Syariah Mandiri berada di zona "aman" tidak mengalami kesulitan keuangan.

Hasil prediksi yang berbeda ditunjukkan oleh model Springate S-Score yang mengindikasikan bahwa PT. Bank Muamalat Indonesia berada di wilayah financial distress dan berpotensi bangkrut. Kondisi ini dipengaruhi oleh penjualan perusahaan yang tidak mengalami pertumbuhan signifikan dan banyaknya Non Performing Funding (NPF) yang belum terselesaikan.

Hasil penelitian menunjukkan kesimpulan yang sedikit berbeda antara model Altman Z-Score dan Springate SScore. Namun, pada dasarnya, kondisi kesulitan keuangan tercermin pada beberapa variabel mendasar seperti penjualan, pertumbuhan laba atau laba yang dapat dihasilkan, beban operasional serta efisiensi yang dapat dilakukan oleh perusahaan. Pengelolaan aset yang baik juga turut memberikan kontribusi pada efisiensi perbankan syariah. 
Perbankan yang bertumpu pada pengumpulan dan penyaluran dana dari masyarakat tidak terlepas dari biaya dan margin. Perbankan dituntut untuk mendapatkan dana berbiaya murah dan menyalurkan dalam bentuk kredit yang murah dan mudah. Inovasi produk. Inovasi produk dan layanan sangat penting di era e-business dan fintech saat ini. Perbankan syariah dituntut untuk menjawab kebutuhan masyarakat dalam kebutuhan jasa keuangan dengan memanfaatkan teknologi informasi dan kerjasama bisnis antara perbankan syariah dengan berbagai merchant.

Selain dari segi perolehan dana, perbankan syariah juga perlu merumuskan kebijakan proses kredit, dimulai dengan seleksi nasabah sampai dengan monitoring dan engagement. Kredit bermasalah adalah sumber masalah bagi pendapatan bank. Jika kredit tidak dikelola dengan baik, maka akan sangat berdampak pada profitabilitas dan kinerja bank.

\section{REFERENSI}

Abrori, H. (2015). Pada Bank Syariah Devisa Dan Non Devisa Dengan Menggunakan Metode Altman Z-Score Periode Diajukan guna memenuhi tugas dan melengkapi syarat guna memperoleh gelar strata satu ( S1) dalam ilmu ekonomi Islam Disusun oleh: Hilman Abrori Program Studi Ekonom.

Africa, L. A. (2016). Financial distress for bankruptcy early warning by the risk analysis on go-public banks in Indonesia. Journal of Economics, Business \& Accountancy Ventura, 19(2), 259.

https://doi.org/10.14414/jebav.v19i2.542

Ali, S. S. (2006). Financial distress and bank failure: Relevance for Islamic banks. Islamic Banking and Finance: Fundamentals and Contemporary Issues, 99-120.

Altman, E. I. (2000). Predicting Financial
Distress of Companies: Revisiting The Z-Score and Zeta Models. Journal of Banking \& Finance.

Avenhuis, J. O. (2013). Testing the generalizability of the bankruptcy prediction models of Altman, Ohlson and Zmijewski for Dutch listed and large non-listed firms. 46p.

Beaver, W. H. (1966). Financial Ratios as Predictors of Failure. Journal of Accounting Research, Volume 4, pp. 71111

Bell, A. R., Brooks, C. \& Prokopczuk, M. (2013). Handbook of Research Methods and Applications in Emprical Finance. s.1.:Edward Elgar Publishing Ltd.

Ebrahim, M. S.,\& Joo, T. K. (2001). Islamic Banking in Brunei Darussalam. International Journal of Social Economics, 28(4), pp. 314-337.

Fakhri Husein, M., \& Tri Pambekti, G. (2014). Precision of the models of Altman, Springate, Zmijewski, and Grover for predicting the financial distress. Journal of Economics, 17(3), 405-416.

https://doi.org/10.14414/jebav.14.17030 10

Financial Distress And Bank Failure: Lessons From Closure Of Ihlas Finans In Turkey. (2007). 2-52.

Fitriasari, F., Pascasarjana, M., Ekonomi, F., \& Brawijaya, B. U. (1999). the Growth of Islamic Banking. 1-10.

Garbois, C. (A. T. K., Gourp, C. (A. T. K., von Pock, A., \& Bhatnagar, M. (A. T. K. (2012). The Future of Islamic Banking. Security Dialogue, 24(4), 383-396. https://doi.org/10.1177/09670106930240 04005

Ghozali, I. (2013). Aplikasi Analisis Multivariate Dengan Program IBM SPSS 21 Update PLS Regresi. Semarang: Badan Penerbit Universitas Diponegoro

Hanif, M., Tariq, M., \& Tahir, A. (2012). 
Comparative performance study of conventional and Islamic banking in Pakistan. International Research Journal of Finance and Economics, 83(83), 6272 .

Hendarsyah, D. F. (2018). “ The Development of Islamic Banking and Finance in Indonesia and Policy Responses ."

Hosen, M. N., \& Nada, S. (2013). Pengukuran Tingkat Kesehatan Dan Gejala Financial Distress Bank Umum Syariah. Jurnal Economia, 9(2), 215226.

Iqbal, M., Riyadi, S., Sabrianti, P., \& Afidah, A. N. (2018). Mapping of Islamic Bank Financial Distress in Indonesia. Jurnal Economia, 14(2), 138-157. https://doi.org/10.21831/economia.v14i2 .20482

Ismal, R. (2010). How Do Islamic Banks Manage Liquidity Risk? An Empirical Survey on the Indonesian Islamic Banking Industry. Kyoto Bulletin of Islamic Area Studies, 3(2), 54-81.

Januri, E. N. S. \& Diyanti, A. (2017). The Analysis of Bankruptcy Potential Comparative by Altman Z-Score, Springate, and Zmijewski Methods at Cement Companies listed in In Indonesia Stock Exchange. IOSR Journal of Business and Management, 19(10), 8087.

Kordestani, G., Biglari, V., \& Bakhtiari, M. (2011). Ability of Combinations of Cash Flow Components to Predict Financial DistressPinigų srautų komponentų derinių galimybès numatyti finansinius sunkumus. Verslas: Teorija Ir Praktika, 12(3), 277-285.

https://doi.org/10.3846/btp.2011.28

Kurnia, R. A. E., Sawarjuwono, T., \& Herianingrum, S. (2017). Manajemen risiko pembiayaan untuk mengantisipasi kondisi financial distress pada bank syariah. Journal of Islamic Economics
Lariba, 3(2), 51-64.

Kurniawati, L., \& Kholis, N. (2004). Analisis Model Prediksi Financial Distress Pada Perusahaan. Proceeding, 145-153.

Kurnia, R. A. E., Sawarjuwono, T. \& Herianingrum, S. (2017). Manajemen Risiko Pembiayaan untuk Mengantisipasi Kondisi Financial Distress Pada Bank Syariah. Kurnia, Journal of Islamic Economis Lariba, 3(2), pp. 51-64.

Meiliawati, A., \& Isharijadi, I. (2018). Analisis Perbandingan Model Springate Dan Altman Z Score Terhadap Potensi Financial Distress (Studi Kasus Pada Perusahaan Sektor Kosmetik Yang Terdaftar Di Bursa Efek Indonesia). Assets: Jurnal Akuntansi Dan Pendidikan, 5(1), 15. https://doi.org/10.25273/jap.v5i1.1183

Pendahuluan, I. (2016). Keywords : Financial Distress, Islamic Bank, Global Crisis, Altman Z-Score. 900-914.

Plat, H. \& Plat, M. B. (2002). Predicting Financial Distress. Journal of Financial Service Professionals, 56, 12-15.

Ratna, I. dan M. (2018). Analisis FaktorFaktor Yang Mempengaruhi Kondisi Financial Distress Pada Perusahaan Yang Delisting Dari Jakarta Islamic Index Tahun 2012-2016. Jurnal Tabarru', 1(1), 51-62. 